\title{
Presence of the red jollytail, Brachygalaxias bullocki (Regan, 1908) (Galaxiformes: Galaxiidae), in freshwater forested wetlands from Chile
}

\author{
Francisco Correa-Araneda ${ }^{1,2,3^{*}}$, Patricio De Los Ríos ${ }^{2,3}$ and Evelyn Habit ${ }^{4}$
}

\begin{abstract}
Background: Brachygalaxias bullocki (Regan, 1908) is a small-sized freshwater fish species (41 to $46 \mathrm{~mm}$ ) and endemic to Chile. Its biology has still various knowledge gaps, and its distribution range has been reduced in the last decade due to human intervention.

Findings: In this article, for the first time, its presence in forested wetlands of Chile ( $38^{\circ} 52^{\prime}$ to $39^{\circ} 02^{\prime} \mathrm{S}$ ) is documented. The presence of this species in these ecosystems is restricted to wetlands with permanent water regime and depths ranging from 15.7 to $83.5 \mathrm{~cm}$.

Conclusions: The physicochemical habitat conditions show important seasonal variations, suggesting that B. bullocki is resistant to a wide range of temperatures, as well as different levels of dissolved oxygen and conductivity.
\end{abstract}

Keywords: Brachygalaxias bullocki; Fish fauna; Forested wetlands; Conservation

\section{Findings}

Brachygalaxias bullocki (Regan, 1908) is an endemic, smallsized (41 to $46 \mathrm{~mm}$ ) fish species (Stokell 1954; Cifuentes et al. 2012). It is endemic to Chile and still several knowledge gaps about its biology exist (Habit and Victoriano 2012). It is a strict freshwater species inhabiting a wide variety of habitats, such as wetlands and floodplains in large rivers, small streams and littoral zones in lakes (McDowall 1971; Campos 1985). B. bullocki prefers habitats with submerged vegetation (both terrestrial and aquatic), either riffles or pools (García et al. 2012). Its distribution range has been described from the Itata River $\left(36^{\circ} 28^{\prime} \mathrm{S}\right)$ to the Maullín River $\left(41^{\circ} 06^{\prime} \mathrm{S}\right)$ and in the Chiloé Island $\left(41^{\circ} 45^{\prime}\right.$ to $43^{\circ} 25^{\prime}$ S) (Habit and Victoriano 2012). However, this distribution range has been reduced in the last decade mainly in those basins affected by high human intervention (Habit et al. 2010), as a result of forestry, urban growth, effluent discharges and species introduction (Ortiz-Sandoval et al. 2009; Correa-Araneda et al. 2010).

\footnotetext{
* Correspondence: francisco.correa@ifop.cl

'Environmental Department, Aquaculture Research Division, Fisheries Development Institute, Balmaceda Avenue 252, Puerto Montt 5502276, Chile

${ }^{2}$ Environmental Sciences School, Faculty of Natural Resources, Catholic

University of Temuco, P.O. Box 15-D, Temuco 4813302, Chile

Full list of author information is available at the end of the article
}

Consequently, B. bullocki changes in the past 26 years from a vulnerable status of conservation (Glade 1988; Campos et al. 1998) to almost endanger (MMA 2014). Our goal is to document, for the first time, the presence of this species in forested wetlands of Chile, providing more evidence on the high conservation value of these ecosystems.

Fish samples were taken every 2 months, between April 2011 and March 2012, in five forested wetlands $\left(38^{\circ} 33^{\prime}\right.$ to $39^{\circ} 02^{\prime}$ S) (Figure 1A, Table 1) by means of a hand net. The largest possible number of microhabitats were sampled for $10 \mathrm{~min}$ (water column, islets, banks, roots, stems) $(n=6)$. Voucher individuals were preserved for further taxonomic identification (McDowall 1973; Ruiz and Marchant 2004).

In order to characterize the habitat, physicochemical parameters of the water were in situ measured ( $\mathrm{pH}$, conductivity, dissolved oxygen, temperature and turbidity). In addition, water samples were taken for their subsequent laboratory analysis (sulfate, total phosphorous, nitrates and total suspended solids). The hydroperiod of the wetlands was determined by means of autonomous sensors of water level (НОBO U20-001-02), which were calibrated for measurements at 1-h intervals during a period of 1 year (April 2011 to March 2012).

The results showed that all fish specimens collected corresponded to B. bullocki $(n=9)$ (Figure 1B). Although 


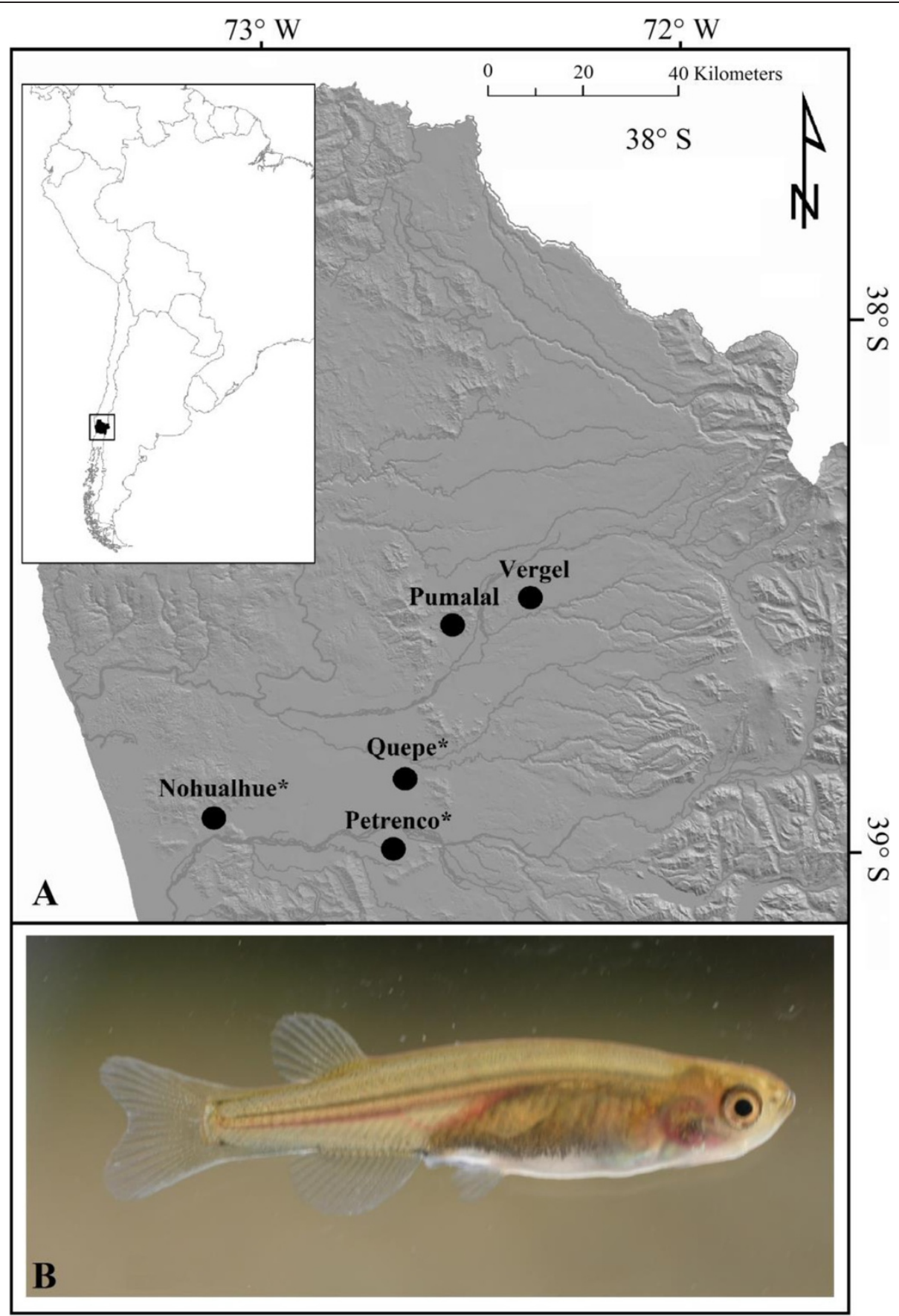

Figure 1 Location map of the studied wetlands (A) and image of an adult Brachygalaxias bullocki (B). *Wetlands where B. bullocki was recorded.

there may be certain features similar to the conspecific species Brachygalaxias gothei (Busse 1982), the latter species has been only described for small ponds near Talca $\left(35^{\circ} 25^{\prime} 33.23^{\prime \prime} \mathrm{S}\right.$ to $\left.71^{\circ} 39^{\prime} 31.94^{\prime \prime} \mathrm{W}\right)$ (SUBPESCA 2005). In addition, Berra et al. (1995), Dyer (2000) and Ruiz and Marchant (2004) propose that B. gothei is a synonym of $B$. bullocki. The same criterion was used in the conservation status classification processes (MMA 2014).
B. bullocki was collected only in wetlands with a permanent water regime (Petrenco, Quepe, Nohualhue) (Table 1), which remained flooded throughout the year with depths that ranged between 15.7 and $83.5 \mathrm{~cm}$. In contrast, wetlands with temporary water regime (Vergel, Pumalal) had a dry phase that lasted between 150 and 160 days (Table 1), which would be critical for the presence of B. bullocki. Beyond to water regime, all study sites are metabolically 
Table 1 Presence and absence of Brachygalaxias bullocki in wetlands and their geographical, biological, morphometric and hydrological characterizations

\begin{tabular}{|c|c|c|c|c|c|}
\hline & Petrenco & Quepe & Nohualhue & Vergel & Pumalal \\
\hline Brachygalaxias bullocki & $x$ & $x$ & $x$ & & \\
\hline South coordinates & $39^{\circ} 02^{\prime} 20.29^{\prime \prime}$ & $38^{\circ} 52^{\prime} 26.36^{\prime \prime}$ & $38^{\circ} 58^{\prime} 0.72^{\prime \prime}$ & $38^{\circ} 33^{\prime} 43.64^{\prime \prime}$ & $38^{\circ} 35^{\prime} 55.34^{\prime \prime}$ \\
\hline West coordinates & $72^{\circ} 39^{\prime} 45.27^{\prime \prime}$ & $72^{\circ} 36^{\prime} 56.02^{\prime \prime}$ & $73^{\circ} 4^{\prime} 34.59^{\prime \prime}$ & $72^{\circ} 19^{\prime} 27.93^{\prime \prime}$ & $72^{\circ} 30^{\prime} 59.57^{\prime \prime}$ \\
\hline Vegetation association & Temu-pitra & Temu-pitra & Temu-pitra & Temu-pitra & Temu-pitra \\
\hline Wetland surface (ha) & 269 & 346 & 107 & 138 & 192 \\
\hline Elevation (masl) & 94 & 95 & 26 & 182 & 158 \\
\hline Hydric regime & Permanent & Permanent & Permanent & Temporary & Temporary \\
\hline Hydroperiod (days) & 365 & 365 & 365 & 199 & 215 \\
\hline Non-flooded phase (days) & 0 & 0 & 0 & 166 & 150 \\
\hline Maximum depth (cm) & 69.7 & 59.9 & 83.5 & 82.4 & 51.5 \\
\hline Minimum depth $(\mathrm{cm})$ & 30.8 & 15.7 & 22.1 & 0 & 0 \\
\hline
\end{tabular}

similar, since they accommodate temu-pitra forests (Correa-Araneda et al. 2011, 2012), belonging to the vegetation association of Blepharocalyo-Myrceugenietum exsuccae (Ramírez et al. 1995).

The preference of $B$. bullocki in habitats with submerged vegetation (García et al. 2012), where it lays its eggs (Campos 1972), is consistent with its presence in forested wetlands, dominated by native woody vegetation from 10 to $15 \mathrm{~m}$ in height (Correa-Araneda et al. 2012) of Myrtaceae family trees, including Myrceugenia, Blepharocalyx, Luma, Tepualia and Winteraceae (Drimys winteri JR et G. Forster) (Hauenstein et al. 2005; Correa-Araneda et al. 2011). Dead individuals from this vegetation create islets, roots and branches (Correa-Araneda et al. 2012), generating a highly heterogeneous habitat. These environments are particularly different from other wetlands, due to the permanent presence of large woody debris (LWD), low water temperatures and low light penetration. Therefore, these wetlands are metabolically similar to headwater rivers (Vannote et al. 1980), but with no current velocity.
Indeed, these heterogeneous habitats when combined with low or null water current velocity result in optimal conditions for B. bullocki.

As reported by Campos (1972), B. bullocki feeds mainly on insect larvae, chironomids, amphipods, copepods and cladocerans. Consistently, Correa-Araneda et al. (In press) reported Chironomidae, Crustacea and Oligochaeta as dominant invertebrate taxa in permanent and temporary wetlands. Particularly in permanent wetlands, Chironomidae, Asellidae, Hyalella sp., Oligochaeta and Smicridea sp. are the taxa with the highest frequency of occurrence.

Physicochemical characteristics of the water in sites where B. bullocki was present showed an important seasonal variability, with some extreme values considering fish persistence (Table 2). Water has acidic $\mathrm{pH}$ (4.4 to 6.4) and has low conductivity in winter $(37 \mu \mathrm{S} / \mathrm{cm})$ and medium in summer $(92 \mu \mathrm{S} / \mathrm{cm})$. Dissolved oxygen showed drastic variations between winter ( 6.5 to $10.5 \mathrm{mg} / \mathrm{L}$ ) and summer $(2.2$ to $3.6 \mathrm{mg} / \mathrm{L})$. These levels recorded in summer, generally insufficient for the survival of fish fauna, indicate that

Table 2 Mean values of physicochemical variables recorded in forested wetlands $(n=3)$

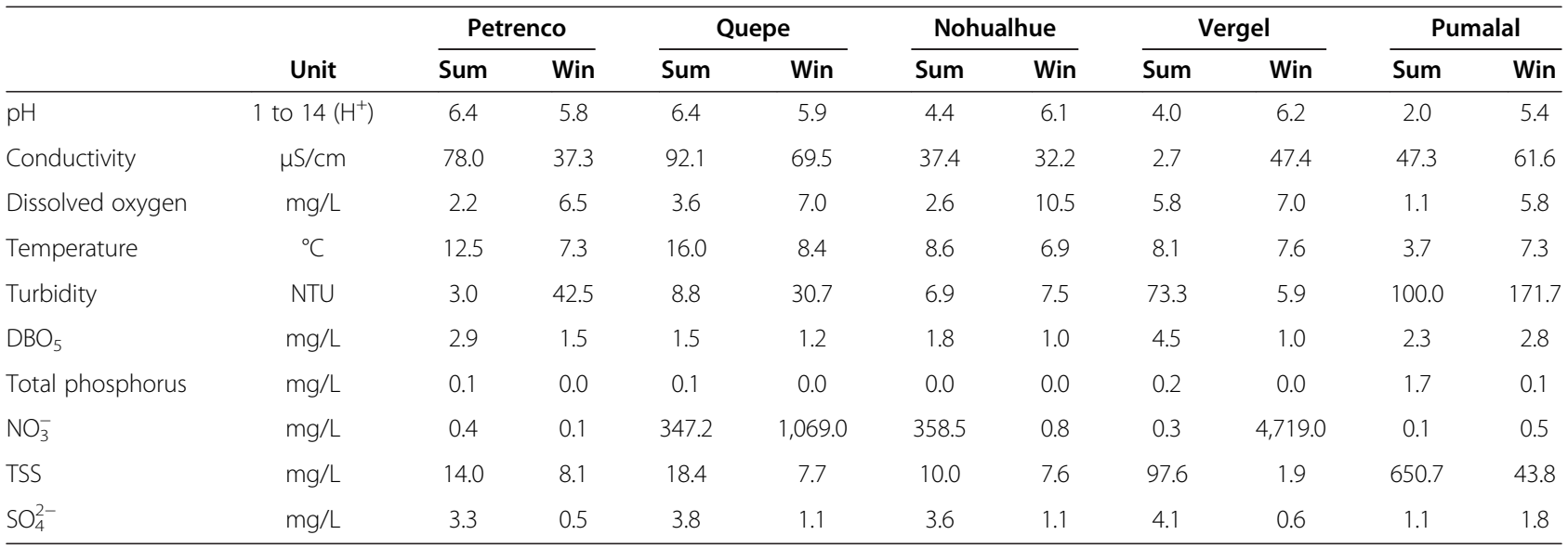

Sum, summery; Win, wintry; TSS, total suspended solids. 
in this season B. bullocki should migrate to more oxygenated areas, perhaps to ecotones with fluvial ecosystems, as recorded by Valdovinos et al. (2012). Temperature had the highest values in summer, ranging from $8.6^{\circ} \mathrm{C}$ to $16^{\circ} \mathrm{C}$. Turbidity was higher in winter, peaking at 42.5 nephelometric turbidity units (NTU), whereas in summer the average maximum was $8.8 \mathrm{NTU}$. The same happened with total suspended solids, with a maximum value of $18.4 \mathrm{mg} / \mathrm{L}$ in summer. Seasonal changes of these variables are mainly due to an increase in sediment due to surface runoff during winter, which would involve significant changes to the fish fauna, as the decrease in light penetration affects the predator-prey relation (ANZECC and ARMCANZ 2000). Phosphorus levels were generally low, unlike nitrate, which reached $1,069 \mathrm{mg} / \mathrm{L}$ in the wetland Quepe in winter. Sulfate, used by primary producers, presented the same trend as the temperature and inversely to the dissolved oxygen, with the highest values in summer $(3.8 \mathrm{mg} / \mathrm{L})$. Therefore, summer conditions in these forested wetlands represent extreme conditions for the fish fauna. This is particularly relevant for B. bullocki, considering that young of the year of the species occur during spring and summer (Valdovinos et al. 2012).

This new record of B. bullocki reinforces the high conservation value of the forested wetlands and informed new characteristics of the habitat of an endemic fish species, with severe conservation status.

\section{Competing interests}

The authors declare that they have no competing interests.

\section{Authors' contributions}

FC carried out the sample collection and species identification and drafted the manuscript. PDR participated in the sampling and water physicochemical analyses and helped to draft the manuscript. EH carried out the final identification of the species and helped to draft and translate the manuscript. All authors read and approved the final manuscript.

\section{Acknowledgements}

The authors wish to express their thanks for the support at the DIUC-VRID 213.310.063-1 AP project, Native Forest Research Fund (035-2010) from the Chilean National Forest Corporation and the MECESUP UCT 0804 project. Special thanks to Anaysa Elgueta and Jorge Gonzalez for their support in species identification.

\section{Author details}

'Environmental Department, Aquaculture Research Division, Fisheries Development Institute, Balmaceda Avenue 252, Puerto Montt 5502276, Chile. ${ }^{2}$ Environmental Sciences School, Faculty of Natural Resources, Catholic University of Temuco, P.O. Box 15-D, Temuco 4813302, Chile. ${ }^{3}$ Nucleus of Environmental Studies, Catholic University of Temuco, P.O. Box 15-D, Temuco 4813302, Chile. ${ }^{4}$ Department of Aquatic Systems, Faculty of Environmental Sciences and EULA-Chile Centre Universidad de Concepción, P.O. Box 160-C, Concepción 4070386, Chile.

Received: 5 August 2014 Accepted: 14 October 2014

Published online: 12 November 2014

\section{References}

ANZECC and ARMCANZ (2000) Australian guidelines for water quality monitoring and reporting. National Water Quality Management Strategy No. 7. Australian and New Zealand Environment and Conservation Council, Agriculture and Resource Management Council of Australia and New Zealand, Canberra, 251 pp
Berra TM, Feltes RM, Ruiz VH (1995) Brachygalaxias gothei from south-central Chile, a synonym of B. bullocki (Osteichthys: Galaxiidae). Ichthyological Exploration of Freshwaters 6:227-234

Campos H (1972) Kariology of three galaxiids fishes Galaxias maculatus, G. platei and Brachygalaxias bullocki. Copeia 2:368-370

Campos H (1985) Distribution of fishes in the Andean rivers in the south of Chile. Arch Hydrobiol 104(2):169-191

Campos H, Dazarola G, Dyer B, Fuentes L, Gavilán JF, Huaquín L, Martínez G, Meléndez R, Pequeño G, Ponce F, Ruiz VH, Siefeld W, Soto D, Vega R, Vila I (1998) Categorías de Conservación de peces nativos de aguas continentales de Chile. Boletín del Museo Nacional de Historia Natural, Santiago de Chile 47:101-122

Cifuentes R, González J, Montoya G, Jara A, Ortíz N, Piedra P, Habit E (2012) Relación longitud-peso y factor de condición de los peces nativos del río San Pedro (cuenca del río Valdivia, Chile). Gayana Especial 76:101-110

Correa-Araneda F, Rivera R, Urrutia J, De Los Ríos P, Contreras Á, Encina-Montoya F (2010) Efectos de una zona urbana sobre la comunidad de macroinvertebrados bentónicos de un ecosistema fluvial del sur de Chile. Limnetica 29(2):183-194

Correa-Araneda F, Urrutia J, Figueroa R (2011) Estado del conocimiento y principales amenazas de los humedales boscosos de agua dulce de Chile. Rev Chil Hist Nat 84:325-340

Correa-Araneda F, Urrutia J, Soto-Mora Y, Figueroa R, Hauenstein E (2012) Effects of the hydroperiod on the vegetative and community structure of freshwater forested wetlands, Chile. J Freshw Ecol 1:1-12

Correa-Araneda F, Gómez-Capponi F, Díaz ME, Ovalle K, Urrutia R, Figueroa R (In press) Benthic macroinvertebrates community patterns of Mediterranean forested wetlands and their relation with changes in the hydroperiod. Limnetica, Spain

Dyer B (2000) Systematic review and biogeography of the freshwater fishes of Chile. Estudios Oceanológicos (Chile) 19:77-98

García A, González J, Habit E (2012) Caracterización del hábitat de peces nativos en el río San Pedro (cuenca del rio Valdivia, Chile). Gayana Especial 76:36-44

Glade A (ed) (1988) Libro Rojo de los Vertebrados Terrestres de Chile, Corporación Nacional Forestal (CONAF), Primera Edición. Ministerio de Agricultura, Santiago

Habit E, Victoriano P (2012) Composición, origen y valor de conservación de la Ictiofauna del Río San Pedro (Cuenca del Río Valdivia, Chile). Gayana Especial 73:10-23

Habit E, Piedra P, Ruzzante D, Walde SJ, Belk MC, Cussac VE, Gonzalez J, Colin N (2010) Changes in the distribution of native fishes in response to introduced species and other anthropogenic effects. Glob Ecol Biogeogr 19:697-710

Hauenstein E, González M, Peña-Cortés F, Muñoz-Pedreros A (2005) Diversidad vegetal en humedales costeros de la región de La Araucanía. In: Smith-Ramírez C, Armesto JJ, Valdovinos C (eds) Historia, diversidad y ecología de los bosques costeros de Chile. Editorial Universitaria, Santiago, pp 197-205

McDowall RM (1971) The galaxiid fishes of South America. Zool J Linnean Soc 50(1):33-73

McDowall RM (1973) Limitation of the genus Brachygalaxias Eigenmann, 1928 (Pisces: Galaxiidae). J R Soc N Z 3:193-197

MMA (2014) Clasificación de especies según estado de conservación. Ministerio del Medio Ambiente, Gobierno de Chile, Chile. Version 2014. http://www. mma.gob.cl/clasificacionespecies. Accessed 14 July 2014

Ortiz-Sandoval JJ, Ortiz N, Cifuentes R, González J, Habit E (2009) Respuesta de la comunidad de peces al dragado de ríos costeros de la región del BioBío (Chile). Gayana 73(1):64-75

Ramírez C, San Martín C, San Martín J (1995) Estructura florística de los bosques pantanosos de Chile sur-central. In: Armesto J, Villagrán C, Arroyo MK (eds) Ecología de los bosques nativos de Chile. Editorial Universitaria, Santiago, pp 215-234

Ruiz VH, Marchant M (2004) Ictiofauna de aguas continentales chilenas. Proyecto de Docencia N 98-071. Universidad de Concepción, Chile, 356 pp

Stokell G (1954) Contributions to galaxiid taxonomy. Trans Roy Soc New Zeal 82:411-418

SUBPESCA (2005) Antecedentes técnicos para establecer medidas de protección (veda) a especies ícticas nativas en aguas continentales. Departamento de Pesquerías, SUBPESCA, Chile, $19 \mathrm{pp}$

Valdovinos C, Habit E, Jara A, Piedra P, González J, Salvo J (2012) Dinámica espacio-temporal de 13 especies de peces nativos en un ecotono lacustre-fluvial de la Cuenca del Río Valdivia (Chile). Gayana Especial 76:45-58

Vannote RL, Minshall GW, Cummings KW, Sedell JR, Cushing CE (1980) The river continuum concept. Can J Fish Aquat Sci 37:130-137

doi:10.1186/s40693-014-0020-4

Cite this article as: Correa-Araneda et al:: Presence of the red jollytail, Brachygalaxias bullocki (Regan, 1908) (Galaxiformes: Galaxiidae), in freshwater forested wetlands from Chile. Revista Chilena de Historia Natural 2014 87:20. 